\title{
Detection of infectious salmon anemia virus in sea water by nested RT-PCR
}

\author{
Trond Løvdal ${ }^{1, *}$, Øivind Enger ${ }^{2}$ \\ ${ }^{1}$ Department of Microbiology, University of Bergen, Jahnebakken 5, PO Box 7800, 5020 Bergen, Norway \\ ${ }^{2}$ Forinnova AS, Thormøhlensgate 55, 5008 Bergen, Norway
}

\begin{abstract}
A method to detect low levels of infectious salmon anemia virus (ISAV) in environmental samples has been developed. The method is based on concentrating the viruses by tangential flow filtration and ultracentrifugation prior to amplification of the extracted viral RNA by nested reverse transcription polymerase chain reaction (RT-PCR). In the current investigation, seawater samples from salmon holdings were used for ISAV identification. ISAV was detected in seawater samples from a salmon holding site and from a vessel transporting salmon in 2 consecutive trials of the methodology. When known concentrations of ISAV were added to 21 of sea water, 5.5 viruses ml ${ }^{-1}$ (corresponding to a tissue culture titer of $\mathrm{TCID}_{50} 1.6 \times 10^{-2} \mathrm{ml}^{-1}$ ) were detected using this method.
\end{abstract}

KEY WORDS: Infectious salmon anemia virus · Nested RT-PCR · Virus concentration · Salmo salar

\section{INTRODUCTION}

Numerous reports have been made about the detection of infectious salmon anemia virus (ISAV), including immunochemical, histochemical and reverse transcription polymerase chain reaction (RT-PCR) techniques, but so far all have involved the detection of virus from tissue samples. ISAV is an orthomyxoviruslike single-stranded RNA virus (Mjaaland et al. 1997) that causes high mortalities of 15 to $100 \%$ when infecting farmed Atlantic salmon Salmo salar L. (Thorud 1991, Rimstad et al. 1999). Methods for detection of ISAV in tissue from chronically infected fish and asymptomatic carriers have been developed (Devold et al. 2000, Griffiths \& Melville 2000), but we are not aware of any published reports reporting detection of ISAV directly from seawater samples. Such a method will make it possible to determine whether the virus is present in the water.

A rapid assay for the detection of ISAV in water may contribute to an understanding of the distribution of the virus in the environment. Such an assay would also

*E-mail: trond.lovdal@im.uib.no be advantageous for surveillance of possible reservoirs and to monitor the survival of ISAV in the environment. In addition, it may be possible to detect the virus in waste water from slaughterhouses, fish farms and vessels transporting fish. The method may be considered to be a tool for infectious salmon anemia (ISA) risk analysis and disease control. In this study we report specific detection of ISAV in seawater samples by concentration followed by nested RT-PCR. Before salmon holdings were sampled, the detection level and sensitivity of the method were investigated. We also discuss the benefits that nested RT-PCR provides in the detection of the virus.

\section{MATERIALS AND METHODS}

Virus isolates. Purified ISAV was kindly provided by Dr K. E. Christie (Intervet Norbio, Bergen) and Dr H. Kongshaug (Institute of Marine Research, Bergen), who also measured the virus titers in the respective isolates by calculating the $\mathrm{TCID}_{50}$ (tissue culture infective dose producing cytopathic effect in $50 \%$ of inoculated cultures) using the method of Kärber (1931). The viruses were originally isolated from Atlantic salmon 
kidney (ASK) cells, and passed on to ASK cells and salmon head kidney (SHK) cells. The provided viruses were counted using a fluorescent microscope (Zeiss) with 100× objectives (Plan Apochromat, Zeiss) after staining with a 250-fold dilution of SYBR Gold (Molecular Probes) as described by Noble \& Fuhrman (1998). Dilution series of the viruses were made in natural sea water. Negative control samples were included in all experiments.

Sampling. Environmental samples were collected from 2 marine grow-out sites (Holdings 1 and 2) and from a well boat transporting infected salmon from one of these sites (Holding 2) to the slaughterhouse. All samples were collected in volumes of 21 in sterile polyethylene bottles, immediately beneath the waters's surface. The samples were kept in the dark and on ice until they were processed in the laboratory. Times from sampling to processing were $5 \mathrm{~h}$ (Holding 1), $15 \mathrm{~h}$ (Holding 2) and $7 \mathrm{~h}$ (well boat samples). Two samples from the well boat were collected $4 \mathrm{~h}$ after loading of salmon. From Holding 1, three samples were collected from net pens holding ISA-positive salmon. From Holding 2, two samples were collected, one from a net pen holding ISA-positive salmon and another from 80 to $100 \mathrm{~m}$ downstream from the pens. In addition, 1 sample from each site was collected upstream from the pens.

Concentration of virus. Two liter samples were concentrated to $80 \mathrm{ml}$ by tangential flow filtration (TFF) through a 100000 molecular weight cut off (MWCO) polyethersulfone membrane (Vivaflow 200, Vivascience) according to the manufacturer's protocol. A $40 \mathrm{ml}$ sample of the concentrates was pre-centrifuged twice at $10580 \times g$ for $30 \mathrm{~min}$ at $4^{\circ} \mathrm{C}$. The samples were then ultracentrifuged at $141000 \times g$ for $2 \mathrm{~h}$ at $4^{\circ} \mathrm{C}$ in an SW 28 rotor (Beckman). The supernatants were carefully removed, and the tubes were placed upside down on the bench for $30 \mathrm{~min}$ to allow the pellets to dry. The concentration efficiency was evaluated after the addition of known concentrations of ISAV $\left(5.5 \times 10^{5}\right.$ virus $\mathrm{ml}^{-1}\left[\mathrm{TCID}_{50} 1.6 \times 10^{3} \mathrm{ml}^{-1}\right.$ ] to $5.5 \times 10^{-6}$ virus $\mathrm{ml}^{-1}$ $\left[\mathrm{TCID}_{50} 1.6 \times 10^{-8} \mathrm{ml}^{-1}\right.$ ]) into 21 of natural sea water.

RNA extraction. One milliliter of TriPure Isolation Reagent (Boehringer Mannheim) was added to the tubes containing the pellets at room temperature. Pellets were resuspended thoroughly by repetitive pipeting and RNA was isolated as described by the manufacturer. Extracted RNA pellets were resuspended thoroughly in $50 \mu \mathrm{l}$ nuclease-free water and incubated for $10 \mathrm{~min}$ at $60^{\circ} \mathrm{C}$.

Initial PCR experiments. To develop a suitable PCR based procedure for detection of ISAV, a series of initial experiments was performed. Two different PCR approaches were investigated. One approach applied single step RTPCR with either the ISA $1 \mathrm{~F}$ and ISA $1 \mathrm{R}$ primers or the ISA $2 \mathrm{~F}$ and ISA $2 \mathrm{R}$ primers. The second approach applied nested RT-PCR with the primers ISA $1 \mathrm{~F}$ and ISA $2 \mathrm{R}$ in the first round of amplification (PCR A) and the primers ISA $2 \mathrm{~F}$ and ISA $1 \mathrm{R}$ in the second round of amplification (PCR B). All primers were designed based on the genome sequence from segment 8 on the ISAV genome published by Mjaaland et al. (1997). The sequence is deposited in the European Molecular Biology Laboratory (EMBL), GenBank, and the DNA Databank of Japan (DDBJ) under accession no. Y10404. The primers were synthesized by MWG Biotech. The primers are presented in Table 1.

Contrary to the treatment of the environmental samples, the initial PCR experiments were carried out in the absence of sample concentration or RNA extraction (i.e. purified ISAV was heated to $95^{\circ} \mathrm{C}$ for $5 \mathrm{~min}$ and transferred directly to the PCR). According to the results from the initial experiments, the nested RT-PCR approach was applied for the detection of ISAV in the environmental samples as outlined below.

RT-PCR. Complementary DNA (cDNA) synthesis and the first round of amplification were carried out as a single tube RT-PCR assay using the Access RT-PCR kit (Promega). Isolated viral RNA was heated at $95^{\circ} \mathrm{C}$ for 5 min prior to addition to the RT-PCR mix. Five microliters of isolated viral RNA were added to $20 \mu \mathrm{l}$ RT-PCR mix containing $1 \times$ AMV/Tfl (avian myeblastosis virus) reaction buffer, $0.2 \mathrm{mM}$ (each) deoxynucleotide triphosphates (dNTPs), $1 \mathrm{mM} \mathrm{MgSO}_{4}, 0.1 \mathrm{U}$

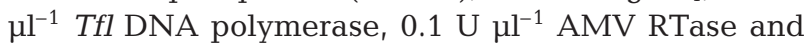
$1 \mu \mathrm{M}$ of each of the 2 primers ISA $1 \mathrm{~F}$ and ISA 2R. PCR mixtures were transferred directly from ice to a thermocycler (PerkinElmer), where the RT reaction was carried out at $48^{\circ} \mathrm{C}$ for $45 \mathrm{~min}$ for the synthesis of cDNA, followed by a 2 min incubation step at $95^{\circ} \mathrm{C}$ for denaturation of the RNA/cDNA hybrid and inactivation of the AMV RTase. The RT reaction was followed by an amplification cycle (PCR A) consisting of a denaturation step $\left(95^{\circ} \mathrm{C}, 45 \mathrm{~s}\right)$, a primer annealing step $\left(55^{\circ} \mathrm{C}, 45 \mathrm{~s}\right)$ and an elongation step $\left(68^{\circ} \mathrm{C}, 2 \mathrm{~min}\right)$. This

Table 1. Sequence and location of the primers tested for use in amplification of the eighth segment of the infectious salmon anemia virus (ISAV). The sequences are given in $5^{\prime}$ to $3^{\prime}$ polarity. All primers correspond to segment 8 (Y10404) on the ISAV genome published by Mjaaland et al. (1997). cDNA: complementary DNA

\begin{tabular}{|llc|}
\hline Primer & Sequence & $\begin{array}{c}\text { Location } \\
\text { on cDNA }\end{array}$ \\
\hline ISA 1F & 5'-ACT TAC ACT TGG CGG GGA AAG C-3' & 161-183 \\
ISA 1R & 5'-CGT CTT GGC ATC CTG ACT CTT C-3' & $360-382$ \\
ISA 2F & 5'-ATC AGT CGA GCG ACG ATG ACT C-3' & $261-283$ \\
ISA 2R & 5'-CAT TTG CTC TTC AGG GGC CTT C-3' & $457-479$ \\
\hline
\end{tabular}


cycle was repeated 40 times. A final 7 min elongation step at $68^{\circ} \mathrm{C}$ was performed to improve the quality of the end product and to extend cut off products to full length. The expected size of the RT-PCR product was 318 base pairs (bp).

Nested RT-PCR. Five microliters of the product from PCR A was transferred to $20 \mu \mathrm{l}$ PCR B mix, which contained all the components of the RT-PCR mix with one exception. The AMV RTase was replaced by nuclease free water. In PCR B the initial primer pair was replaced by ISA $2 \mathrm{~F}$ and ISA $1 \mathrm{R}, 1 \mu \mathrm{M}$ of each. The amplification was carried out as described for PCR A. The expected size of the nested RT-PCR product was $121 \mathrm{bp}$. The specificity of the primer sets was determined by sequence analysis of nested RT-PCR products.

Visualization of PCR products. The final PCR product was visualized after electrophoresis on a $1.5 \%$ agarose $10 \times$ Tris-acetate-EDTA (TAE) gel containing $2.5 \times 10^{-4} \mu$ g ethidium bromide $\mathrm{ml}^{-1}$. The electrophoresis was carried out at $300 \mathrm{~V}$ for $15 \mathrm{~min}$.

Sequence analysis. Nested RT-PCR products were prepared for sequence analysis using Amicon Microcon-PCR Centrifugal Filter Devices (Millipore) as described by the manufacturer, and analyzed with an ABI PRISM 3700 DNA Analyzer (Perkin-Elmer Biosystems) using the ABI PRISM Big Dye Terminator Cycle Sequencing Ready Reaction Kit (Perkin-Elmer Biosystems) as described by the manufacturer. The amplified sequence from the nested RT-PCR was compared with published sequences by use of the search tool basic local alignment search tool (BLAST).

\section{RESULTS}

The initial PCR experiments showed that the nested RT-PCR procedure detected $1.8 \times 10^{5}$ viruses $\mathrm{ml}^{-1}$

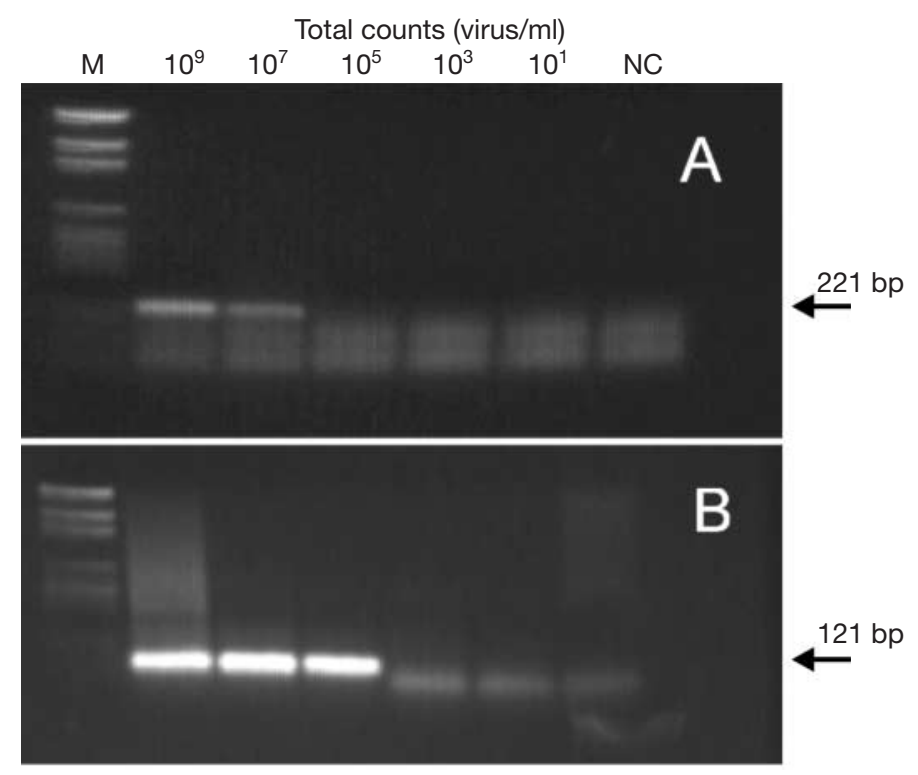

Fig. 1. Agarose gels showing PCR products amplified from infectious salmon anemia virus (ISAV) by (A) conventional RT-PCR and (B) nested RT-PCR. DNA ladder (M) is pGEM DNA marker. Negative control (NC) was nuclease free water

$\left(\right.$ TCID $_{50} 100 \mathrm{ml}^{-1}$ ) even in the absence of sample concentration or RNA extraction (Fig. 1). This method not only was 100 times more sensitive than the most sensitive single step RT-PCR performed using the primers ISA $1 \mathrm{~F}$ and ISA $1 \mathrm{R}$ but also prevented primer-dimer formation (Fig. 1).

According to our experiments, after concentration and RNA extraction, the smallest detectable inoculum in the culture assays was 5.5 viruses $\mathrm{ml}^{-1}$ TCID $_{50}$ $1.6 \times 10^{-2} \mathrm{ml}^{-1}$ ) when nested RT-PCR was performed (Fig. 2).

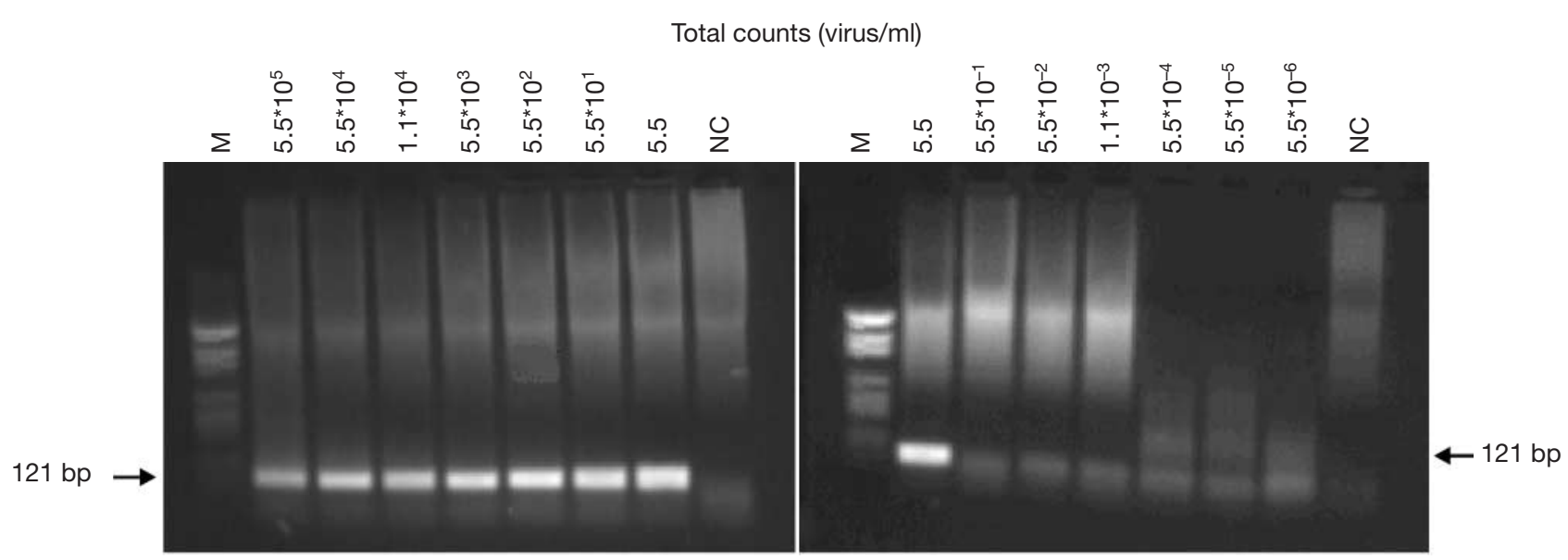

Fig. 2. Agarose gels showing nested RT-PCR products amplified from infectious salmon anemia virus (ISAV) inoculated in sea water. DNA ladder (M) is pGEM DNA marker. Negative controls (NC) were stored sea water 


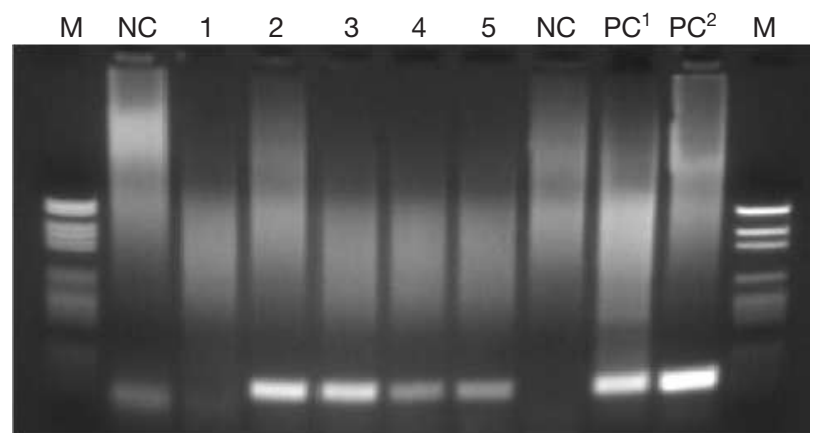

Fig. 3. Agarose gels showing nested RT-PCR products amplified from samples collected at Holding 1. Lane 1: sample collected directly upstream; Lanes 2, 3: samples collected directly from pens; Lanes 4, 5: pooled samples from pens. DNA ladder (M) is pGEM DNA marker. Negative controls (NC) were stored sea water. Positive controls: $10^{6}$ viruses $\mathrm{ml}^{-1}$ $\left(\mathrm{PC}^{1}\right), 10^{3}$ viruses $\mathrm{ml}^{-1}\left(\mathrm{PC}^{2}\right)$

All 3 samples collected from net pens at Holding 1 were positive (Fig. 3). Two parallels of 1 of these samples were pooled in the RNA extraction step to see whether this would yield more intensive PCR signals. This did not have the desired effect. Although both parallels were positive, the signals from both parallels were weaker than the signals from the other 2 positive samples (Fig. 3).

None of the samples collected at Holding 2 were positive, but the 2 samples collected at the well boat transporting salmon from Holding 2 were positive by nested RT-PCR (Fig. 4). The samples collected upstream from the pens were negative. The specificity of the primers was confirmed by sequencing 1 nested RT-PCR product from Holding 1 and 1 nested RT-PCR product from 1 of the ISAV isolates provided. The sequenced segment from the environmental sample showed $100 \%$ homology (67 of 67 identical bases) with 10 isolates of ISAV from Norway.

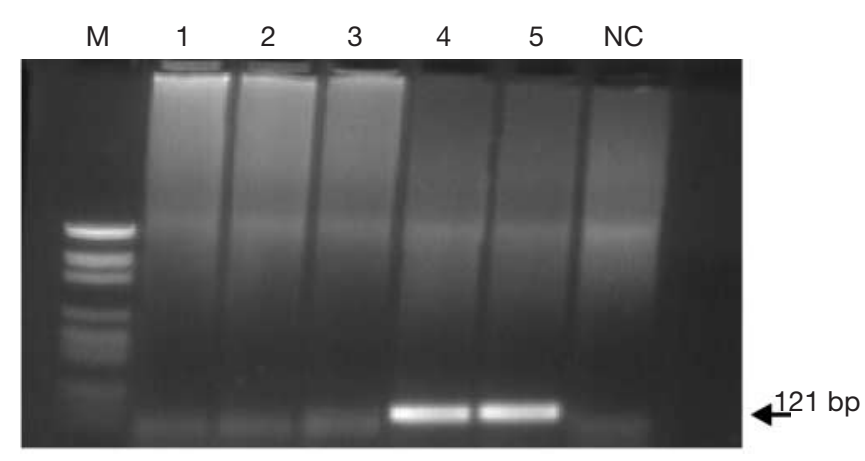

Fig. 4. Agarose gel showing nested RT-PCR products from samples collected at Holding 2 and from the well boat transporting salmon from Holding 2. Lane 1: sample collected upstream from pens; Lane 2: sample collected downstream from pens. Lane 3: sample collected directly from pen. Lanes 4, 5: samples from well boat. DNA ladder (M) is pGEM DNA marker. Negative control (NC) was stored sea water

\section{DISCUSSION}

The purpose of this work was to develop and test an efficient method for the concentration of ISAV in water samples from the environment, and to develop a specific and sensitive PCR for detection of the virus. The detection sensitivity of PCR is related to 2 factors: (1) the effectiveness of recovery of virus from samples and (2) the degree of final purity of recovered virus. Taken together, these 2 factors influence the amount and purity of viral nucleic acid recoverable from a sample and determine whether PCR-inhibiting substances that lower test sensitivity are present in the final sample (Metcalf et al. 1995).

TFF has previously been shown to be an effective method for concentration of fish pathogenic viruses (Watanabe et al. 1988, Batts \& Winton 1989, Paul et al. 1991). Soule et al. (2000) detected low concentrations of poliovirus, rotavirus and hepatitis A virus in water samples using TFF combined with ultracentrifugation and RT-PCR using a method very similar to the method described here. TFF followed by low speed centrifugation increases the PCR detection sensitivity 10-fold relative to when ultracentrifugation is the only centrifugation step (data not shown). Consequently, a multistep approach to concentrate environmental water samples and to minimize the presence of inhibitors was developed. Through our procedure, ultrafiltration recovers the virus with minimum loss, and the low speed centrifugation step eliminates or reduces potential PCR-inhibiting substances prior to concentrating the virus by ultracentrifugation. This study is the first in which TFF combined with low speed centrifugation and ultracentrifugation was used for the concentration of ISAV from environmental water samples.

The sensitivity of the PCR reaction for detection of ISAV in the water samples was significantly increased through the use of nested RT-PCR. As shown in Fig. 1, nested RT-PCR was 100 times more sensitive than the most sensitive conventional RT-PCR performed using the primers ISA $1 \mathrm{~F}$ and ISA $1 \mathrm{R}$, producing a product of an expected size of $221 \mathrm{bp}$. The detection level after the second round of amplification (PCR B) was 10000 times lower than the detection level after the first round of amplification (PCR A) in nested RT-PCR (data not shown). With nested RT-PCR, we also found that the formation of primer-dimers was avoided. These results are consistent with the results achieved by Opitz et al. (2000), who found that nested RT-PCR was more sensitive than RT-PCR for detection of ISAV in kidney tissue. Use of nested primers provides an additional level of specificity and increases amplification efficiency by minimizing nonspecific primer annealing (Haqqi et al. 1988). The amount of target sequences increases in the first round of amplification, leading to 
a more target specific amplification in the second step. The efficiency of amplification from the sequence produced in the first nesting step is also enhanced due to a more complete denaturation (Porter-Jordan et al. 1990). Dilution of the DNA product from the first round of amplification into a second PCR mix may also effectively dilute potential inhibitors to an acceptable level and allow for successful amplification (Steffan \& Atlas 1991). Fig. 2 shows that the amount of PCR product from the nested PCR increased as the initial viral load decreased. This is also evident from the 2 controls in Fig. 3. This may be due to the amount of template added to the second round of PCR (PCR B). The primary PCR reaction (PCR A) produced high amounts of PCR product when the viral load was high and decreasing amounts as the template was diluted (data not shown). For the PCR B, $5 \mu$ from each of the PCR A reactions was used as template, and hence in the samples with the highest viral load the template amount for PCR B was not optimal and produced fewer PCR products. On the other hand, undetectable PCR products from PCR A give enough template for PCR B. As the purpose of this study was to develop a sensitive PCR assay for the detection of ISAV that could be applied to environmental water samples, we did not attempt to avoid this feature because it is unlikely that the level of ISAV in the environmental samples would be too high for efficient amplification (i.e. $>10^{6}$ viruses $\mathrm{ml}^{-1}$ ) when performed as outlined in this report. However, by reducing the number of amplification cycles in the second or in both steps (Porter-Jordan et al. 1990), or by further dilution of the PCR A (Mullis \& Faloona 1987, Sauvaigo et al. 1990) or PCR B products (Paul et al. 1990), false negatives due to a suboptimal level of template may be avoided.

The specificity of the primers used in the nested RT-PCR was confirmed by sequence analysis of the amplified products. Furthermore, nested RT-PCR products of the expected size were amplified only when RNA extracted from ISAV-contaminated water was used as a template.

The fieldwork presented in this report shows that ISAV can be detected even if the mortality rate due to ISA is $<0.05 \% \mathrm{pen}^{-1} \mathrm{~d}^{-1}$. The Norwegian Animal Health Authority recommends that mortality due to ISA be above this level before slaughter of infected fish is ordered (Hastings et al. 1999). At Holding 2, ISAV could not be detected, even though the mortality rate was higher than at Holding 1. This discrepancy is probably due to the $15 \mathrm{~h}$ delay before these samples were processed. The persistence of ISAV in sea water is uncertain, but in another study we found that the decay rate for ISAV inoculated in sterilized sea water was $6 \% \mathrm{~h}^{-1}$, leading to a 10 -fold decline after approximately $40 \mathrm{~h}$ (data not shown). This suggests that ISAV is unstable in sea water and that samples must be processed as soon as possible after sampling. This theory is supported by the fact that ISAV was detected in samples from the well boat transporting salmon from Holding 2 to the slaughterhouse. These samples were processed $7 \mathrm{~h}$ after sampling. Experimental trials have shown that infected fish shed large amounts of the virus for several weeks before they show any visible signs of ISA (Christie et al. 1993, Totland et al. 1996). The present method allows detection of the shed virus before mortality due to ISA becomes significant. Our findings that ISAV is indeed present in detectable numbers in sea water in fish farms where the fish are suffering from ISA and in sea water in ships used for transport of diseased fish should be used to improve regulations aimed at limiting the spread of ISA. Further, our new technique allowing detection of ISAV in environmental samples may also be used to monitor environmental release of ISAV from activities such as farming, transport and slaughter of diseased fish.

Acknowledgements. Karen Elina Christie (Intervet Norbio, Bergen), and Heidi Kongshaug and Brit Hjeltnes (Institute of Marine Research, Bergen) are gratefully acknowledged for their donations of ISAV. We also acknowledge Ruth-Anne Sandaa and Tonje Castberg (Department of Microbiology, University of Bergen) for technical support and for critically reading the manuscript. This study was financially supported by the Norwegian Research Council (grant no. 123787/120).

\section{LITERATURE CITED}

Batts WN, Winton JR (1989) Concentration of infectious hematopoietic necrosis virus from water samples by tangential flow filtration and polyethylene glycol precipitation. Can J Fish Aquat Sci 46:964-968

Christie KE, Hjeltnes B, Uglenes I, Winton JR (1993) Determination of buoyant density and sensitivity to chloroform and freon for the etiological agent of infectious salmon anaemia. Dis Aquat Org 15:225-228

Devold M, Krossøy B, Aspehaug V, Nylund A (2000) Use of RT-PCR for diagnosis of infectious salmon anaemia virus (ISAV) in carrier sea trout Salmo trutta after experimental infection. Dis Aquat Org 40:9-18

Griffiths S, Melville K (2000) Non-lethal detection of ISAV in Atlantic salmon by RT-PCR using serum and mucus samples. Bull Eur Assoc Fish Pathol 20:157-162

Haqqi TM, Sarkar G, David CS, Sommer SS (1988) Specific amplification with PCR of a refractory segment of genomic DNA. Nucleic Acids Res 16:11844

Hastings T, Olivier G, Cusack R, Bricknell I, Nylund A, Binde M, Munro P, Allan C (1999) Infectious salmon anaemia. Bull Eur Assoc Fish Pathol 19:286-288

Kärber G (1931) Beitrag zur kollektiven Behandlung pharmakologischer Reihenversuche. Arch Exp Pathol Pharmakol 162:480-483

Metcalf TG, Melnick JL, Estes MK (1995) Environmental virology: from detection of virus in sewage and water by isolation to identification by molecular biology - a trip of over 50 years. Annu Rev Microbiol 49:461-487

Mjaaland S, Rimstad E, Falk K, Dannevig BH (1997) Genomic 
characterization of the virus causing infectious salmon anemia in Atlantic salmon (Salmo salar L.): an orthomyxolike virus in a teleost. J Virol 71:7681-7686

Mullis KB, Faloona FA (1987) Specific synthesis of DNA in vitro via a polymerase-catalyzed chain reaction. Methods Enzymol 155:335-350

Noble RT, Fuhrman JA (1998) Use of SYBR Green I for rapid epifluorescence counts of marine viruses and bacteria. Aquat Microb Ecol 14:113-118

Opitz HM, Bouchard D, Anderson E, Blake S, Nicholson B, Keleher W (2000) A comparison of methods for the detection of experimentally induced subclinical infectious salmon anaemia in Atlantic salmon. Bull Eur Assoc Fish Pathol 20:12-22

Paul JH, Cazares L, Thurmond J (1990) Amplification of the rbcl gene from dissolved and particulate DNA from aquatic environments. Appl Environ Microbiol 56:1963-1966

Paul JH, Jiang SC, Rose JB (1991) Concentration of viruses and dissolved DNA from aquatic environments by vortex flow filtration. Appl Environ Microbiol 57:2197-2204

Porter-Jordan K, Rosenberg EI, Keiser JF, Gross JD, Ross AM, Nasim S, Garrett CT (1990) Nested polymerase chain reaction assay for the detection of cytomegalovirus overcomes false positives caused by contamination with fragmented DNA. J Med Virol 30:85-91

Rimstad E, Falk K, Mikalsen AB, Teig A (1999) Time course tissue distribution of infectious salmon anaemia virus in

Editorial responsibility: Jo-Ann Leong,

Corvallis, Oregon, USA experimentally infected Atlantic salmon Salmo salar. Dis Aquat Org 36:107-112

Sauvaigo $\mathrm{S}$, Fouquè $\mathrm{B}$, Roget $\mathrm{A}$, Livache $\mathrm{T}$, Bazin $\mathrm{H}$, Chypre C, Teoule R (1990) Fast solid support detection of PCR amplified viral DNA sequences using radioiodinated or hapten labeled primers. Nucleic Acids Res 18: 3175-3183

Soule H, Genoulaz O, Gratacap-Cavallier B, Chevallier P, Liu JX, Seigneurin JM (2000) Ultafiltration and reverse transcription-polymerase chain reaction: an efficient process for poliovirus, rotavirus and hepatitis A virus detection in water. Water Res 34:1063-1067

Steffan RJ, Atlas RM (1991) Polymerase chain reaction: applications in environmental microbiology. Annu Rev Microbiol 45:137-161

Thorud KE (1991) Infectious salmon anaemia, transmission trials, haematological, clinical chemical and morphological investigations. DSc thesis, Norwegian School of Veterinary Medicine, Oslo

Totland GK, Hjeltnes BK, Flood PR (1996) Transmission of infectious salmon anaemia (ISA) through natural secretions and excretions from infected smolts of Atlantic salmon Salmo salar during their presymptomatic phase. Dis Aquat Org 26:25-31

Watanabe RA, Fryer JL, Rohovec JS (1988) Molecular filtration for recovery of waterborne viruses of fish. Appl Environ Microbiol 54:1606-1609

Submitted: May 31, 2001; Accepted: November 19, 2001

Proofs received from author(s): April 4, 2002 